работ в послеаварийный период. Представленный анализ действий японской стороны и международных организаций по смягчению и ликвидации последствий аварии и известные результаты моделирования распространения радиоактивных продуктов в окружающей среде позволяют сделать важные шаги в понимании основных причин, уроков и последствий большой аварии на АЭС Fukushima-Daiichi. Полученные оценки носят предварительный характер и предполагают дальнейший мониторинг и анализ развития вопросов по обеспечение экологической безопасности и устранению последствий аварий на АЭС.

Ключевые слова: Фукусимская авария, экологические последствия, радиоактивные выбросы.

I.L. Kozlov. Analysis of ecological consequences and lessons of the Fukushima accident. The events that occurred at the nuclear power plant (NPP) Fukushima-Daiichi forced all the world nuclear community and government bodies of ecological safety regulation to return again, after Chernobyl accident, to the need of revaluating the safety of all operating and designed NPPs. The consequences connected with emissions of radioactive products to the environment increase the validity of studying and analyzing the environmental issues, while evaluating the works done in the postemergency period. The presented analysis of the actions of the Japanese side and of the international organizations on mitigation and elimination of consequences of the accident, as well as the results of modeling of radioactive products distribution in environment allow to take important steps in understanding the main reasons, processes and consequences of the big accident on the nuclear power plant Fukushima-Daiichi. The obtained estimates are preliminary and require further monitoring and analysis of issues on ecological security and elimination of consequences of accidents at NPPs.

Keywords: Fukushima accident; ecological consequences; radioactive emissions.

Рецензент д-р техн. наук, проф. Одес. нац. политехн. ун-та Максимов М.В.

Поступила в редакцию 24 марта 2014 г.

UDC 534.222.2+536.46+662.215.1

V.E. Volkov, DSc, Department Chairman, Odessa

National Academy of Food Technologies

\title{
DEFLAGRATION-TO-DETONATION TRANSITION AND THE DETONATION INDUCTION DISTANCE ESTIMATION
}

Introduction. Turbojet and turbofan engines at flight Mach numbers exceeding 3 are very expensive. In particular, pulse detonation engine (PDE) is more attractive energetically for flight Mach numbers of about $3 \ldots 4$ [1]. But in order to use detonations for propulsion and to realize the corresponding thermodynamic advantages (they lead to reduced fuel consumption) some problems must be resolved. These problems deal mainly with achievement and control of detonations in a propulsion device. Among these problems are [1]:

- necessity of low-energy source for the detonation initiation;

- knowledge of geometry of the combustion chamber to promote detonation initiation and survival at lowest possible pressure lost.

Both problems are related to fundamental problem of deflagration-to-detonation transition and calculating of the detonation induction distance. Calculating of the detonation induction distance (and the detonation wave formation time) is also very important for explosion safety. And yet there are no reliable analytical methods for such calculating.

DOI: 10.15276/opu.1.43.2014.21

(C) V.E. Volkov, 2014 
Literature review. Results of experimental researches for the deflagration-to-detonation transition (DDT) are summarized by Michael Nettleton [2]. The key ideas for physical and chemical mechanisms of transition from deflagration to detonation are described in book [3]. Multidimensional timedependent solutions of the Navier-Stokes equations are used to study the processes leading to DDT in an energetic reactive gas mixture $[4,5]$. Numerical simulations of DDT, obtained by Elaine Oran (US Naval Research Laboratory) and her co-authors $[4,5]$, describe the transition phenomena in details, e.g. the development of hot spots (ignition centers) and spontaneous reaction waves are investigated. But either these numerical solutions or others [6...8] need a lot of computer time. And it is not convenient for problems of the DDT control, i. e. for real-time computing (especially for the explosion safety control).

Research goal. Developing a mathematical model of DDT that leads to simple analytical estimates for the detonation induction distance (DDT run-up distance) and the detonation wave formation time (DDT time) without detailed phenomena consideration

Research description. The reason of DDT is instability of laminar flames. Physical model for DDT contains the next stages:

- there exists a possibility of the laminar flame instability;

- as the result of two-dimensional (multidimensional) flame instability the flame front distortion and turbulent combustion take place;

- flame accelerates because of the burning-surface area increase [9];

- accelerating flame generates shock wave and detonation.

Solutions for the detonation induction distance $X_{d}$ and the DDT time $\tau_{s}$ are obtained by $\mathrm{H}$. Jones and M. Nettleton [2] for different types of the flame acceleration $g_{f}$. If $g_{f}=$ const, that is flame acceleration is constant, distance $X_{f}$ between the point of ignition and the point, of flame positioning during the shock wave formation can be estimated as [2]

$$
X_{f}=\frac{2 a_{1}^{2}}{g_{f} \beta_{f}^{2}\left(\gamma_{1}+1\right)^{2}},
$$

where $B_{f}=$ const $\left(0<\beta_{f} \leq 1, \beta_{f}=0,9\right.$ in most cases $)$;

$a_{1}$ sonic speed for inflammable mixture;

$\gamma_{1}$ the ratio of specific heats for this mixture.

Distance $X_{s}$ between the point of ignition and the point, where the shock wave is generated can be assessed as [2]

$$
X_{s}=\beta_{f}\left(\gamma_{1}+1\right) X_{f},
$$

that is

$$
X_{s}=\frac{2 a_{1}^{2}}{g_{f} \beta_{f}\left(\gamma_{1}+1\right)} .
$$

For open spaces either wide channels and tubes with smooth walls [2]

$$
X_{s} \approx X_{d} .
$$

So to obtain of the detonation induction distance $X_{d}$ (or $X_{s}$ ) formula it is necessary to estimate the flame acceleration $g_{f}$.

Such estimate is based on the flame stability problem solution. This problem is solved for the flames propagating in open spaces through viscous incompressible environment [10]. The solution is enlarged to cylindrical tubes. Case of instability wave length $\lambda_{m}$ for the fastest growth rate of perturbation amplitude is obtained [10]. 
Arc distance $l$ for the distorted flame, corresponding to $\lambda_{m} / 2$ is

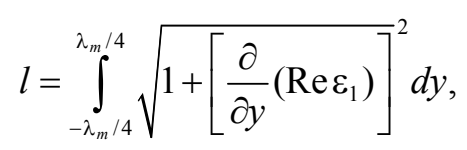

where $\varepsilon_{1}(y, t)=A_{01} h^{-1} \exp (i h y-i \omega t)$ flame leading edge perturbation;

$h=2 \pi / \lambda>0$ wave number;

$\lambda$ wave length;

$i$ unit imaginary number;

$\omega$ complex number (eigen-value);

$y$ spatial coordinate;

$t$ time;

$A_{01}$ arbitrary constant;

$\operatorname{Re} \varepsilon_{1}$ real part of $\varepsilon_{1}$.

The quantity $\left[\frac{\partial}{\partial y}\left(\operatorname{Re} \varepsilon_{1}\right)\right]^{2}$ is small [10]. So

$$
l \approx \int_{-\lambda_{m} / 4}^{\lambda_{m} / 4}\left\{1+\frac{1}{2}\left[\frac{\partial}{\partial y}\left(\operatorname{Re} \varepsilon_{1}\right)\right]^{2}\right\} d y,
$$

and

$$
l=\frac{\lambda_{m}}{2}+\int_{0}^{\lambda_{m} / 4}\left[\frac{\partial}{\partial y}\left(\operatorname{Re} \varepsilon_{1}\right)\right]^{2} d y .
$$

It is obvious that for $\lambda=\lambda_{m}$

$$
\operatorname{Re} \varepsilon_{1}=A_{01} \frac{\lambda_{m}}{2 \pi} \cos \frac{2 \pi y}{\lambda_{m}} \cos \frac{2 \pi y}{\lambda_{m}} \exp \left(\frac{2 \pi z u_{1} t}{\lambda_{m}}\right),
$$

where $z=-\frac{i \omega}{h u_{1}}$ is dimensionless eigen-value [10];

$u_{1}$ is laminar combustion velocity.

Let us assume

$$
K=A_{01} \exp \left(\frac{2 \pi z u_{1} t}{\lambda_{m}}\right) .
$$

Then

$$
\begin{gathered}
\int_{0}^{\lambda_{m} / 4}\left[\frac{\partial}{\partial y}\left(\operatorname{Re} \varepsilon_{1}\right)\right]^{2} d y=K^{2} \int_{0}^{\lambda_{m} / 4} \sin ^{2} \frac{2 \pi y}{\lambda_{m}} d y, \\
\int_{0}^{\lambda_{m} / 4}\left[\frac{\partial}{\partial y}\left(\operatorname{Re} \varepsilon_{1}\right)\right]^{2} d y=\left.K^{2}\left(\frac{y}{2}-\frac{\lambda_{m}}{8 \pi} \sin \frac{4 \pi y}{\lambda_{m}}\right)\right|_{0} ^{\lambda_{m} / 4},
\end{gathered}
$$

and finally

$$
\int_{0}^{\lambda_{m} / 4}\left[\frac{\partial}{\partial y}\left(\operatorname{Re} \varepsilon_{1}\right)\right]^{2} d y=K^{2} \frac{\lambda_{m}}{8} .
$$




\section{Substituting (4) into (2), we obtain}

$$
l=\frac{\lambda_{m}}{2}\left(1+\frac{K^{2}}{4}\right)
$$

It is evident that

$$
\frac{l}{\lambda_{m} / 2}=1+\frac{K^{2}}{4} .
$$

So the ratio of areas for the disturbed flame and the planar flame will equal

$$
\left(\frac{l}{\lambda_{m} / 2}\right)^{2}=\left(1+\frac{K^{2}}{4}\right)^{2} \text {. }
$$

By law of areas

$$
\frac{u_{f}}{u_{1}}\left(1+\frac{K^{2}}{4}\right)^{2},
$$

where $u_{f}$ is the flame propagation velocity.

Quantity $K$ is small. So

$$
u_{f}=u_{1}\left(1+\frac{K^{2}}{2}\right)
$$

and

$$
\frac{d u_{f}}{d t}=u_{1} K \frac{d K}{d t} .
$$

Obviously the shock wave is generated when flame propagating velocity is close to the sonic speed $a_{1}$ for initial inflammable mixture. Let us assume that such velocity can be reached within time $\tau_{s}$. Then, due to (5)

$$
\begin{gathered}
a_{1}=u_{1}\left(1+\frac{K^{2}\left(\tau_{s}\right)}{2}\right), \\
1+\frac{K^{2}\left(\tau_{s}\right)}{2}=\frac{1}{M_{1}},
\end{gathered}
$$

and

$$
K^{2}\left(\tau_{s}\right)=\frac{2\left(1-M_{1}\right)}{M_{1}},
$$

where $M_{1}=\frac{u_{1}}{a_{1}}$ the Mach number.

Due to (3)

$$
\frac{d K}{d t}=\frac{2 \pi z u_{1}}{\lambda_{m}} K
$$

so

$$
\frac{d u_{f}}{d t}=\frac{2 \pi z u_{1}^{2}}{\lambda_{m}} K^{2}
$$


and, in particular,

$$
\frac{d u_{f}}{d t}\left(\tau_{s}\right)=\frac{2 \pi z u_{1}^{2}}{\lambda_{m}} K^{2}\left(\tau_{s}\right) .
$$

\section{Substituting (6) into (7), we obtain}

$$
\frac{d u_{f}}{d t}\left(\tau_{s}\right)=\frac{4 \pi z u_{1}^{2}\left(1-M_{1}\right)}{\lambda_{m} M_{1}} .
$$

Thus, at the moment when the flame propagating velocity is close to the sonic speed $a_{1}$ the flame is acceleration

$$
g_{f}=\frac{4 \pi z u_{1}^{2}\left(1-M_{1}\right)}{\lambda_{m} M_{1}}
$$

With regard to [10]

$$
\begin{gathered}
z_{0}=\frac{\delta_{2}}{\delta_{2}+1}\left(-1+\sqrt{\delta_{2}+1-\frac{1}{\delta_{2}}}\right) \\
-\left(1+\frac{\delta_{2}}{\delta_{2}+1} z_{0}\right) z_{1}=z_{0}\left[\frac{1}{2}\left(1+\frac{z_{0}}{2}\right)\left(2 \delta_{2}+1\right)+\left(\frac{\delta_{2}}{\delta_{3}}-1\right)+\delta_{2}^{m}\left(\frac{\delta_{2}+1}{\delta_{3}} z_{0}+\delta_{3}+3\right)\right]+ \\
\frac{1}{2}\left(\delta_{2}-1\right)\left(1+2 z_{0}+\frac{z_{0}^{2}}{\delta_{3}}\right) \\
g_{f}=-\frac{z_{0}^{2} u_{1}^{2}\left(1-M_{1}\right)}{2 z_{1} L M_{1}},
\end{gathered}
$$

where $\delta_{2}=\frac{\rho_{1}}{\rho_{2}}, \rho_{1}$ is the initial inflammable mixture density, $\rho_{2}$ is density of combustion products;

$$
\delta_{3}=\delta_{2}-\frac{\delta_{2}-1}{e}
$$

$m=$ const exponent in dependence of dynamic-viscosity coefficient on temperature;

$L$ is the flame thickness.

Substituting (8) into (1), we obtain

$$
X_{s}=-\frac{4 z_{1} L}{\left(1-M_{1}\right) M_{1} z_{0}^{2} \beta_{f}\left(\gamma_{1}+1\right)} .
$$

Formula (9) represents an is analytical estimate for the detonation induction distance.

For DDT time $\tau_{s}$ such approximate estimate will be:

$$
\tau_{s}=\frac{X_{s}}{u_{1}} .
$$

Thus the analytical estimates for DDT run-up distance and for the detonation wave formation time are obtained. Calculation these algebraic formulae is very simple requiring a minimal computer time, but such calculating does not describe the deflagration-to-detonation transition phenomena and its nature in detail.

Results. To verify the proposed mathematical model the calculations of the detonation induction distance $X_{s}$ and of DDT time $\tau_{s}$ have been implemented for different combustible environments. The results are given in Table. 
Detonation induction distance $X_{s}$ and DDT time $\tau_{s}$ for different combustible media

\begin{tabular}{l|c|c}
\hline \multicolumn{1}{c|}{ Combustible medium } & $X_{s}$ & $\tau_{s}$ \\
\hline Gas mixtures near stoichiometry & $10 \mathrm{~mm} \ldots 50 \mathrm{~cm}$ & $0,001 \mathrm{~s} \ldots 5 \mathrm{~s}$ \\
\hline Gas mixtures near concentration combustion limits & $50 \mathrm{~cm} \ldots 5 \mathrm{~m}$ & $5 \mathrm{~s} \ldots 15 \mathrm{~s}$ \\
\hline Fine-dyspersated aerosols and dust suspensions & $1 \mathrm{~m} \ldots 10 \mathrm{~m}$ & $5 \mathrm{~s} \ldots 1 \mathrm{~min}$ \\
\hline Aerosols and dust suspensions & $5 \mathrm{~m} \ldots 15 \mathrm{~m}$ & $15 \mathrm{~s} \ldots 2 \mathrm{~min}$ \\
\hline $\begin{array}{l}\text { Aerosols and dust suspensions near concentration } \\
\text { combustion limits }\end{array}$ & more than $15 \mathrm{~m}$ & more than $2 \mathrm{~min}$ \\
\hline
\end{tabular}

Those results are in good agreement with experimental data for open spaces, wide channels and wide tubes with smooth walls. It is well known [2] that wall roughness and obstacles in channels and tubes do significantly reduce DDT run-up distance and DDT time (in some cases in several times, up to $20 \ldots 50$ times).

Conclusions. Main conclusions of research effected are the following:

- the mathematical model for DDT is based on the flame stability problem solution;

- simple algebraic formulae for estimates of the detonation induction distance (9) and DDT time (10) are obtained;

- formula (9) for the detonation induction distance estimate is useful for PDE designing and for explosion proof projecting;

- formula (10) for DDT time first of all amplifies mathematical support of the automated control systems for the potentially explosive objects;

- due to (9) the detonation induction distance for slow-burning mixtures is much more than for fast-burning mixtures, because this distance is directly proportional the flame thickness $L$ and inversely proportional Mach number $M_{1}$.

\section{Literature / References}

1. Application of Detonation to Propulsion / Edited by G. Roy, S. Frolov, J. Shepherd. - Moscow: TORUS PRESS Ltd., 2004. - $328 \mathrm{p}$.

2. Nettleton, M.A. Gaseous detonations: their nature and control / M.A. Nettleton. - [S.1.]: Springer, 2013. $-255 \mathrm{p}$.

3. Liberman, M. Introduction to Physics and Chemistry of Combustion: Explosion, Flame, Detonation / M. Liberman. - Berlin: Springer, 2010. - 360 p.

4. Khokhlov, A.M. Numerical simulation of deflagration-to-detonation transition: the role of shock-flame interactions in turbulent flames / A.M. Khokhlov, E.S. Oran, G.O. Thomas // Combustion and Flame. 1999. - Vol. 117, Iss. 1-2. - pp. 323 - 339.

5. Oran, E.S. Origins of the deflagration-to-detonation transition in gas-phase combustion / E.S. Oran, V.N. Gamezo // Combustion and Flame. - 2007. - Vol. 148, Iss. 1-2. - pp. $4-47$.

6. Baklanov, D.I. Transition of deflagration to detonation in turbulent flow in pulse detonation engine / D.I. Baklanov, L.G. Gvozdeva, A. Kaltayev, N. B. Scherbak // Application of Detonation to Propulsion. Eds. G. Roy, S. Frolov, J. Shepherd. — Moscow: TORUS PRESS, 2004. — pp. 86 — 90.

7. Ciccarelli, G. Flame acceleration and transition to detonation in ducts / G. Ciccarelli, S. Dorofeev // Progress in Energy and Combustion Science. - 2008. - Vol. 34, Iss. 4. — pp. 499 - 550.

8. Valiev, D. Flame acceleration in channels with obstacles in the deflagration-to-detonation transition / D. Valiev, V. Bychkov, V. Akkerman et al. // Combustion and Flame. — 2010. — Vol. 157, Iss. 5. pp. $1012-1021$.

9. Bradley, D. Flame acceleration due to flame-induced instabilities in large-scale explosions / D. Bradley, T.M. Cresswell, J.S. Puttock // Combustion and Flame. - 2001. - Vol. 124, Iss. 4. - pp. $551-559$.

10. Aslanov, S.K. Instability and Structure of Flames / S.K. Aslanov, V.E. Volkov // Pulsed and Continuous Detonations. - Moscow: TORUS PRESS, 2006. - pp. $28-31$.

\section{AHOTАЦІЯ / АННОТАЦИЯ / ABSTRACT}

B.E. Волков. Перехід горіння в детонацію та оцінка довжини переддетонаційної ділянки. Перехід горіння в детонацію $є$ цікавим як $з$ точки зору вибухобезпеки, так і для проектування імпульсних детонаційних двигунів. Такі 
двигуни вигідні енергетично при польотах з числами Маха, що перевищують 3. Проте перехід дозвукового горіння в детонацію на цей час недостатньо досліджено, що є суттєвою перешкодою як для розв'язання проблем вибухобезпеки, так і для конструювання детонаційних двигунів (авіаційних і ракетних). Метою роботи є дослідження математичних властивостей зазначеного переходу. Запропоновано математичну модель переходу дефлаграції в детонацію, що базується на розв'язанні задачі про стійкість полум'я. Ця модель доповнює сучасну теорію горіння та вибуху та теорію турбулентності. Зроблено теоретичну оцінку довжини переддетонаційної ділянки та часу утворення детонаційної хвилі. Доведено, що довжина переддетонаційної ділянки для повільно згораючих сумішей більше ніж для швидко згораючих. Отримані результати дозволяють вдосконалити математичне забезпечення автоматизованих систем керування вибухонебезпечними об'єктами та проектування детонаційних двигунів.

Ключові слова: горіння, детонація, нестійкість, математична модель, переддетонаційна ділянка.

В.Э. Волков. Переход горения в детонацию и оценка длины преддетонационного участка. Переход горения в детонацию представляет интерес как с точки зрения взрывобезопасности, так и для проектирования импульсных детонационных двигателей. Такие двигатели выгодны энергетически при полетах с числами Маха, превышающими 3. Однако переход дозвукового горения в детонацию в настоящее время исследован недостаточно, что является серьезным препятствием как для решения проблем взрывобезопасности, так и для конструирования детонационных двигателей (авиационных и ракетных). Цель работы состоит в исследовании математических закономерностей указанного перехода. Предложена математическая модель перехода дефлаграции в детонацию, базирующаяся на решении задачи об устойчивости пламени. Данная модель дополняет современную теорию горения и взрыва и теорию турбулентности. Произведена теоретическая оценка длины преддетонационного участка и времени образования детонационной волны. Доказано, что длина преддетонационного участка для медленногорящих смесей больше, чем для быстрогорящих. Полученные результаты позволяют усовершенствовать математическое обеспечение автоматизированных систем управления взрывоопасными объектами и проектирование детонационных двигателей.

Ключевые слова: горение, детонация, неустойчивость, математическая модель, преддетонационный участок.

V.E. Volkov. Deflagration-to-detonation transition and the detonation induction distance estimation. Deflagration-to-detonation transition is interesting both for explosion safety and for the pulse detonation engine designing. Such engines are energetically favorable at flight Mach numbers exceeding 3. But transition from subsonic combustion to detonation is not investigated enough at present, and that is a serious difficulty both to the explosion safety problem solution and to engineering of detonation engines (both aeroengines and rocket engines). The aim of the study is investigation of mathematical laws for the mentioned transition. A mathematical model for deflagration-to-detonation transition that is based on the solution of the flame stability problem is offered. This model amplifies modern theory of combustion and explosion and turbulence theory. Theoretical estimates for the detonation induction distance and for the detonation wave formation time are made. It is proved that the detonation induction distance for a slow-burning mixture is greater than for a fast-burning one. The obtained results make it possible to improve mathematical support of the automated control systems for the dangerously explosive objects and the detonation engine designing.

Keywords: deflagration, detonation, instability, mathematical model, detonation induction distance.

Reviever Dr. techn. sciences, Prof. of Odesa nat. polytechnic univ. Maksimov M.V.

Received June 13, 2014 